\title{
PHARMACOVIGILANCE IN EPILEPTIC PATIENTS USING ANTIEPILEPTIC DRUGS
}

\author{
Paulo Afonso Mei', Maria Augusta Montenegro², \\ Marilisa M. Guerreiro ${ }^{3}$, Carlos A.M. Guerreiro ${ }^{4}$
}

\begin{abstract}
Objective: To investigate the occurrence of adverse effects of antiepileptic drugs (AED) in ch ronic epileptic patients in mono or polytherapy. Method: We evaluated consecutive patients that met the following inclusion criteria: age of 18 years or older, diagnosis of epilepsy for at least one year, stable dose of AED for at least three months. Patients were asked if they had any adverse event related to the AED. After that, they were interviewed according to a detailed semi-structure questionnaire. We also assessed specifically the adverse events in the last four weeks. The data were analyzed regarding the use of monotherapy x polytherapy, and the presence of probable depression (score $>15$ ) according to the Center for Epidemiologic Studies Depression Scale. Results: Sixty-five patients were evaluated, 35 women, mean age 38.3 years; 35 patients were in use of monotherapy and 35 in polytherapy. Only $45(69.2 \%)$ patients spontaneously re p o rted adverse effects. After the formal questionnaire, $63(97 \%)$ patients re f e rred experiencing an adverse event $(p<0.001)$. Seventeen men had adverse events, as opposed to 28 women $(p=0.042)$. When the last four weeks were evaluated, patients with probable depression presented adverse events more frequently $(p<0.0001)$. Conclusion: Our data suggest that adverse events are highly prevalent when a detailed questionnaire is applied and that depression may aggravate the number and intensity of side effects in patients using AEDs.
\end{abstract}

KEY WORDS: antiepileptic drugs, pharmacovigilance, epilepsy, depression, adverse events.

\section{Farmacovigilância em pacientes com epilepsia em uso de drogas antiepilépticas}

\begin{abstract}
RESUMO - Objetivo: Investigar a ocorrência de efeitos adversos das drogas antiepilépticas (DAE) em pacientes com epilepsia crônica tanto em mono quanto em politerapia. Método: Avaliamos consecutivamente os pacientes que preencheram os seguintes critérios de inclusão: idade igual ou superior a 18 anos, diagnóstico de epilepsia por no mínimo um ano, doses estáveis de DAE por no mínimo três meses. Os pacientes foram instados a responder espontaneamente sobre a presença de efeitos colaterais das DAE. Após isto, um questionário formal sobre eventos adversos foi aplicado. Também avaliamos especificamente a presença de queixas nas últimas quatro semanas. Os dados foram analisados levando-se em conta o uso de mono ou politerapia e a presença ou não de provável depressão (índice $>15$ ) segundo o CES-D. Resultados: Sessenta e cinco pacientes foram avaliados, 35 mulheres, idade média 38,3 anos; 35 pacientes estavam em uso de monoterapia e 35 em politerapia. Somente $45(69,2 \%)$ pacientes espontaneamente registraram a p resença de efeitos adversos. Após o questionário formal, $63(97 \%)$ pacientes tiveram queixas $(p<0,001)$. Dezessete homens e 28 mulheres re $p$ o rtaram eventos adversos $(p=0,042)$. Quando as últimas quatro semanas foram analisadas, os pacientes com provável depressão relataram mais freqüentemente a presença de efeitos adversos $(p<0,0001)$. Conclusão: Nossos dados sugerem que efeitos adversos são altamente prevalentes quando um questionário detalhado é aplicado e que depressão pode agravar o número e a intensidade de eventos adversos em pacientes com epilepsia utilizando DAE.
\end{abstract}

PALAVRAS-CHAVE: drogas antiepilépticas, farmacovigilância, epilepsia, depressão, eventos adversos.

Most patients with epilepsy depend on the medical treatment with antiepileptic drugs (AED) to achieve control of their seizures, which occurs in around $60-70 \%$ of the patients ${ }^{1}$. A third of the epilep- tic patients do not obtain seizure control with AED $d$ rugs. For them other treatment options are indicated, eventually surgery. Chronic use of AED may be associated with several systemic and central nervous

Departamento de Neurologia - Faculdade de Ciências Mêdicas (FCM) - Universidade Estadual de Campinas (Unicamp), Cam-pinas SP, Brasil: ${ }^{1}$ Acadêmico de Medicina; ${ }^{2}$ Professor Doutor; ${ }^{3}$ Professor Associado; ${ }^{4}$ Professor Titular. Supported by FAPESP Grant \# 04/01530-4.

Received 12 July 2005, received in final form 22 November 2005. Accepted 29 November 2005.

Dr. Carlos A.M. Guerreiro - Departamento de Neurologia, FCM/Unicamp / C.P. 6111 - 13083-970 Campinas SP - Brasil. E-mail: guerreiro@fcm.unicamp.br 
system adverse events ${ }^{2-15}$. Polytherapy is sometimes used in refractoryepilepsy despite significant increase in the number of the side effects ${ }^{16,17}$. Moreover, there is a considerable incidence of co-morbidity among epileptic patients, such as depression, mainly in those with refractoryepilepsy ${ }^{18-21}$. Quality of life is associated with seizure control, presence of depression and with adverse AED events as well22.

Adverse effects are highly prevalent in the medical treatment of epilepsy. For instance, carbamazepine (CBZ) is one of the main drugs used for focal and generalized seizures, and may cause sedation in $40 \%$ of the patients ${ }^{14}$.

The aim of this study was to investigate the occurrence of adverse events of AED in chronic epileptic patients in mono or polytherapy. We collected spontaneous complaints and compared with a detailed semi-structured questionnaire.

\section{METHOD}

This study was conducted at the epilepsy clinic of our university hospital from June 2003 to December 2004.

We evaluated consecutive patients that met the following inclusion criteria: aged 18 years or older, diagnosis of epilepsy for at least one year, stable dose of AED for at least th ree months, signature of informed consent. Exclusion criteria: uncertain diagnosis of epilepsy, patients with cognitive impairment, change in AED dose in the last three months, refuse to sign the informed consent.
Patients were asked if they had any adverse event related to the AED. After that, regardless of the answer, they were interviewed according to a detailed semi-structure questionnaireabout the presence of adverse events associated with the AED, based on literature ${ }^{22}$ and adapted to Portuguese colloquial terms by the authors.

We also assessed specifically the adverse events in the last four weeks. They were rated as 1 to 4 po ints, according to the following scale: 1 - absent, 2 - rare, 3 - sometimes/mild, 4 - frequent/always ${ }^{22}$.

The data was analyzed regarding the use of monotherapy versus polytherapy, and the presence of probable depression (score $>15$ ) according to the Center for Epidemiologic Studies Depression Scale - CES-D ${ }^{23}$. This scale allows to differentiate three groups of patients according to the score: if the score is 22 or higher, the patient may be suffering from a major depression; if the score is 15 to 21 , the patient may be suffering from mild to moderate depression; if the score is below 15, this test does not indicate that the patient is depressed. The reason to choose this scale is that it has been used in the literature to evaluate epileptic patient during antiepileptic drug treatment ${ }^{22}$.

Statistical analysis was perfo rmed using the chi-square test, Fisher exact test and Student t-test.

\section{RESULTS}

Sixty-five patients were evaluated, 35 women, ages ranging from 20 to 70 years-old (mean $=38.3$ years). Thirty patients were in use of monotherapy and 35 in polytherapy.

Table 1. Frequency of adverse events in the last four weeks versus since the beginning of the treatment.

\begin{tabular}{lcccc}
\hline Adverse event & \multicolumn{2}{c}{ Patients in monotherapy } & \multicolumn{2}{c}{ Patients in polytherapy } \\
& Beginning of treatment & Last four weeks & Beginning of treatment & Last four weeks \\
\hline Emotional liability & - & $14(46.7 \%)$ & - & $17(48.6 \%)$ \\
Fatigue & $14(46.7 \%)$ & $15(50 \%)$ & $15(42.9 \%)$ & $18(51.4 \%)$ \\
Psychomotor agitation & - & $16(53.3 \%)$ & - & $19(54.3 \%)$ \\
Agressivity & $4(13.3 \%)$ & $11(36.7 \%)$ & $4(11.4 \%)$ & $10(28.6 \%)$ \\
Anxiety & - & $15(50 \%)$ & - & $15(42,9 \%)$ \\
Headache & $3(10 \%)$ & $8(26.7 \%)$ & $2(5.7 \%)$ & $17(48.6 \%)$ \\
Hair loss & $4(13.3 \%)$ & $5(16.7 \%)$ & $6(17.1 \%)$ & $9(25.7 \%)$ \\
Skin reactions & 3 & $5(16.7 \%)$ & $11(31.4 \%)$ & $7(20 \%)$ \\
Diplopia or blurred vision & $2(6.7 \%)$ & $4(13.3 \%)$ & - & $11(31.4 \%)$ \\
Dyspepsia & - & $11(36.7 \%)$ & $10(28.6 \%)$ & $17(48.6 \%)$ \\
Gingival hypertrophy & $6(20 \%)$ & $4(13.3 \%)$ & - & $7(20 \%)$ \\
Tremor & - & $12(40 \%)$ & - & $11(31.4 \%)$ \\
Weight gain & - & $5(16.7 \%)$ & $9(25.7 \%)$ & $3(10 \%)$ \\
Dizziness & $5(16.7 \%)$ & $6(20 \%)$ & $11(31.4 \%)$ & $11(31.4 \%)$ \\
Somnolence & $14(46.7 \%)$ & $16(53.3 \%)$ & $13(37.1 \%)$ & $11(31.4 \%)$ \\
Memory impairment & $11(36.7 \%)$ & $14(46.7 \%)$ & - & $23(65.7 \%)$ \\
Sleep disturbance & - & $10(33.3 \%)$ & $13(33.3 \%)$ & $15(42.9 \%)$ \\
Lack of concentration & - & &
\end{tabular}


Table 2. Adverse events in patients using one AED versus those on polytherapy. Data collected from a detailed semi-structured questionnaire.

\begin{tabular}{lccccc}
\hline \multirow{2}{*}{ Adverse event } & \multicolumn{2}{c}{ Monotheraphy } & \multicolumn{2}{c}{ Politheraphy } & $\mathrm{p}$ \\
& Yes & No & Yes & No & \\
\hline Irritability & 4 & 26 & 4 & 31 & 0.815 \\
Dizziness & 5 & 25 & 9 & 26 & 0.376 \\
Memory impairment & 11 & 19 & 13 & 22 & 0.968 \\
Dispiritedness & 14 & 16 & 15 & 20 & 0.758 \\
Oversleeping & 14 & 16 & 11 & 24 & 0.208 \\
Unsteadiness & 3 & 27 & 5 & 30 & 0.600 \\
Headache & 3 & 27 & 2 & 33 & 0.518 \\
Diplopia & 7 & 23 & 18 & 17 & $\mathbf{0 . 0 2 0}$ \\
Change in apetite & 8 & 22 & 10 & 25 & 0.864 \\
Gingival bleeding or hypertrophy & 6 & 24 & 10 & 25 & 0.423 \\
Body hair growth & 2 & 28 & 8 & 27 & 0.071 \\
Alopecia & 4 & 23 & 11 & 24 & 0.084 \\
Unhapiness & 12 & 18 & 11 & 24 & 0.471 \\
Artralgia & 1 & 29 & 3 & 32 & 0.380 \\
Skin Rash/Allergy & 3 & 27 & 6 & 29 & 0.405 \\
Lack of libido & 7 & 23 & 8 & 27 & 0.963 \\
Difficulty of erection (men) & 3 & 12 & 2 & 13 & 0.624 \\
\hline
\end{tabular}

Table 3. Number of points attributed to adverse effects according to their intensity scored by each patient in the last four weeks [scoring scale and CES-D (Center for Epidemiologic Studies Depression Scale) detailed in Method].

\begin{tabular}{lccc}
\hline CES-D $<15$ & \# of patients & CES-D > 15 & \# of patients \\
\hline Scoring 1-20 & $03(7.0 \%)$ & Scoring 1-20 & 0 \\
Scoring 21-30 & $14(32.5 \%)$ & Scoring 21-30 & $1(4.5 \%)$ \\
Scoring 31-40 & $19(44.2 \%)$ & Scoring 31-40 & $5(22.7 \%)$ \\
Scoring greater than 40 & $07(16.3 \%)$ & Scoring greater than 40 & $16(72.8 \%)$ \\
Total & $43(100.0 \%)$ & Total & $22(100 \%)$ \\
\hline
\end{tabular}

When asked about the presence of adverse events, only $45(69.2 \%)$ patients answered positively. However, after the formal questionnaire, 63 (97\%) patients referred experiencing an adverse event related to AEDs $(p<0.001)$. Seventeen men had adverse events, as opposed to 28 women ( $p=0.042$ ).

Table 1 shows the data for each symptom in patients with monotherapy or polytherapy since the introduction of the AED and in the last four weeks. The Student $t$-test showed no difference between the presence of adverse events since the introduction of the AED either on monotheraphy $(p=0.309)$ or polytherapy $(p=0.143)$.

We found that 19 patients in monotherapy had adverse events, as opposed to 26 in polytherapy $(p=0.340)$. Table 2 shows the individual analysis for each symptom, and only diplopia was more frequent in patients with polytherapy.

Twenty-two patients had probable depression according to the Center for Epidemiologic Studies D e p ression Scale; and 18 of them presented adverse events. From the 45 patients without depression, 27 had adverse events $(p=0.115)$. However, when the last four weeks were evaluated separately, patients with probable depression presented adverse events more frequently $(p<0.0001$, Table 3$)$.

\section{DISCUSSION}

The recognition of the most frequent side-effects of AEDs helps clinical monitoring of medical treatment of epilepsy. AEDs more commonly used in our institution are carbamazepine, phenytoin, valpro ate 
and clobazam. Our study revealed that hypersomnia, dizziness, gastrointestinal distress and loss of memory are among the most frequent adverse events in patients taking AED. Our result pointed out that proactive semi-structured query is important to detect adverse events, otherwise not mentioned spontaneously by patients. This finding is in keeping with other studies ${ }^{22,24}$. The number of adverse effects was comparable between mono and polytherapy groups in our patients. However, when each side effect was individually analyzed, diplopia was found to occur more frequently in patients under polytherapy. Several studies have indicated that the incidence of adverse effects increase with the number of dru $\mathrm{g} \mathrm{s}^{25-}$ 27. The small number of patients in this research probably explains because we found no difference between the two groups (monotherapy versus polytherapy).

We found that women reported side effects more frequently than men. Weight gain, cosmetic consequences of the treatment and teratogenic effects of AEDs - in those at childbearing age - usually bring greater concern for women ${ }^{12,28,29}$. Therefore, they may be more aware of the possible side effects and prone to report them.

To the best of our knowledge, the Center for Epidemiologic Studies Depression Scale - CES-D23 is not validated in our country; therefore, we cannot make definitive statements about its use and conclusion in this work. In our study, when the last four weeks were evaluated, patients with probable de pression presented adverse events more frequently than patients without depression. Co-morbidity in epilepsy is a major issue nowadays and, for adults, depression is one of the main conditions associated with epilepsy ${ }^{30-32}$. Adverse AED effects and depression may be the most important negative influences on a person's perception of their current health status $^{22}$. The negative impact of depressive disorders in the quality of life of patients with epilepsy demands that their presence be investigated in every epileptic patient ${ }^{33}$.

To conclude, our data suggest that adverse events must be proactively identified through a systematic questionnaire and that depression may aggravate the number and intensity of side effects in patients using AEDs.

\section{REFERENCES}

1. Mattson RH. Medical management of epilepsy in adults. Neurology 1998;51(Suppl 4):S15-S20.
2. Arroyo S, de la Morena A. Life-threatening adverse events of antiepileptic drugs. Epilepsy Res 2001;47:155-174.

3. Bazil CW. Sleep and epilepsy. Semin Neurol 2002;22:321-327.

4. B runi J. Antiepileptic drug selection and adverse effects: an overview. Can J Neurol Sci 1994;21(Suppl):S3-S6.

5. Buchanan N. The occurrence, management and outcome of antiepileptic drug side effects in 767 patients. Seizure 1992;1:89-98.

6. Dodrill CB. Neuropsychological aspects of epilepsy. Psychiatr Clin N Am 1992;15:383-394.

7. Drane DL, Meador KJ. Epilepsy, anticonvulsant drugs and cognition. Baillieres Clin Neurol 1996;5:877-885.

8. Fer rendelli JA. Pharmacology of antiepileptic drug polypharmacy. Epilepsia 1999;40(Suppl 5):S81-S83.

9. Ferrendelli JA. Concerns with antiepileptic drug initiation: safety, tolerability, and efficacy. Epilepsia 2001;42(Suppl 4):S28-S30.

10. Greenwood RS. Adverse effects of antiepileptic drugs. Epilepsia 2000; 41(Suppl 2):S42-S52.

11. Holland KD. Efficacy, pharmacology, and adverse effects of antiepileptic drugs. Neurol Clin 2001;19:313-345.

12. Jallon P, Picard F. Bodyweight gain and anticonvulsants: a comparative review. Drug Saf 2001;24:969-978.

13. Keyser A, Hekster YA, Termond E, Theeuwes A, Schaap M, Rwiza HT. Side-effects of drugs in epileptic patients. Pharm Weekbl Sci 1990;12: 145-150.

14. Matts on RH. Efficacy and adverse effects of established and new antiepileptic drugs. Epilepsia 1995;36(Suppl 2):S13-S26.

15. Schlienger RG; Shear NH. Antiepileptic drug hypersensitivity syndrome. Epilepsia 1998;39(Suppl 7):S3-S7.

16. Deckers CL. Place of polytherapy in the early treatment of epilepsy. CNS Drugs 2002;16:155-163.

17. Salas-Puig J. Rational anti-epileptic polytherapy: drug interactions and choice of treatment. Rev Neurol 2000;30:886-889.

18. Devinsky O. Cognitive and behavioral effects of antiepileptic drugs. Epilepsia 1995;36(Suppl 2):S46-S65.

19. Ha rden CL, Goldstein MA. Mood disorders in patients with epilepsy: epidemiology and management. CNS Drugs 2002;16:291-302.

20. Paciello N, Mazza M, Mazza S. Depression in epilepsy: symptom or syndrome?. Clin Ther 2002;153:397-402.

21. Schmitz B. Psychiatric syndromes related to antiepileptic drugs. Epilepsia 1999;40(Suppl 10):S65-S70.

22. Gilliam F. Optimizing health outcomes in active epilepsy. Neurology 2002;8(Suppl 5):S9-S20.

23. Radloff LS. The CES-D scale: a self report depression scale for research in the general population. Applied Psychological Measurement 1977; 1:385-401.

24. Gilliam FG, Fessler AJ, Baker G, Vahle V, Carter J, Attarian H. Systematic $\mathrm{s} \mathrm{c}$ reening allows reduction of adverse antiepileptic drug effects. a randomized trial. Neurology 2004; 62:23-27.

25. Deckers CL, Hekster YA, Keyser A, et al. Reappraisal of polytherapy in epilepsy: a critical review of drug load and adverse effects. Epilepsia 1997;38:570-575.

26. Guberman A. Monotherapy or polytherapy for epilepsy? Can J Neurol Sci 1998;25(Suppl):S3-S8.

27. Lammers MW, Hekster YA, Keyser A, et al. Monotehrapy or polytherapy for epilepsy revisited: a quantitative assessment. Epilepsia 1995;36:440-446.

28. Isojavi JI, Tauboll E, Herzog AG. Effect of antiepileptic drugs on reproductive endocrine function in individuals with epilepsy. CNS Drugs 2005;19:207-223.

29. Yerby MS. Pregnancy, teratogenesis, and epilepsy. Neurol Clin 1994;12:749-771.

30. Caplan R, Siddarth P, Gurbani S, et al. Depression and anxiety disorders in pediatric epilepsy. Epilepsia 2005; 46:720-730.

31. Jackson MJ, Turkington D. Depression and anxiety in epilepsy. J Neurol Neurosurg Psychiatry 2005; 76 (Suppl 1):S45-S47.

32. Jones JE, Hermann BP, Woodard JL, et al. Screening for major depression in epilepsy with common self-report depression inventories. Epilepsia 2005; 46:731-735.

33. Kanner AM. Depression in epilepsy: a frequently neglected multifaced disorder. Epilep Behav 2003; 4 (Suppl 4):S11-S19. 